\title{
The Media and Public Agenda among the Malay and Chinese Communities during the 2008 Malaysian General Elections
}

\author{
Syed Arabi Idid \\ Department of Communication \\ International Islamic University Malaysia, Malaysia \\ E-mail: sarabidid@iium.edu.my \\ Chang Peng Kee \\ School of Media and Communication Studies \\ Universiti Kebangsaan Malaysia, Malaysia \\ E-mail: chang@ukm.my \\ Accepted: March 13, 2012 Published: April 16, 2012 \\ URL: http://dx.doi.org/10.5539/ass.v8n5p107
}

Received: February 25, 2012

doi:10.5539/ass.v8n5p107

This paper is partially supported by the research project: INDUSTRI-2011-027.

\begin{abstract}
Media are said to set the public agenda. However, the actual scenario of a public agenda among the Malay and Chinese communities in Malaysia has yet to be ascertained. This study employs both content analysis and survey to examine media and public agenda of two major ethnic groups during the 2008 General Elections. In total, 9,135 news items, relating to elections, were obtained from three major languange newspapers, comprising Utusan Malaysia, Berita Harian, Sin Chew Daily, Nanyang Siang Pau, The Star, and New Straits Times, during the campaign period. There were 12 important issues identified. Overall, the study found media agenda had no significant rank-order correlation with the public agenda, or the important issues raised by 1,454 Malay, Chinese, and Indian respondents nationwide. The same happens to the Malay media agenda with Malay public agenda. The study found the Chinese media agenda to have a significant rank-order correlation with the Chinese public agenda suggesting the newspapers influence among the Chinese readers on what to think about. Ethnic newspapers therefore could be setting the agenda for the various ethnic groups during elections.
\end{abstract}

Keywords: Agenda setting, Malaysian media, Malaysian ethnicity, Malaysian general elections, Political communication

\section{Introduction}

Barisan Nasional (BN), a 14-party coalition, scored an impressive win in the Malaysian General Election and State Elections of 2004. It captured $90 \%$ of the federal seats and, except for the state of Kelantan, all the states came under the control of BN. But in 2008, BN experienced its worst defeat since elections were held in the country. It lost four states to the opposition parties, lost its two-thirds majority in parliament and saw the defeat of so many well known political personalities, including ministers, at the hand of voters. It was a major setback for a coalition party that had governed the country since independence in 1957.

There are several reasons for the significant loses suffered by BN during the $12^{\text {th }}$ Malaysian General Elections held in 2008. Many reasons have been attributed to the major setback, including leadership deficiencies, the government's inability to overcome the increase in the prices of basic necessities, the issues and the party performance among the ruling and the opposition parties (Idid, 2011).

There has been, however, little concern on understanding the role of the press during the elections. The role of the mass media has become integral in studying modern day elections. The pervasive presence of media in society has made it an important vehicle to be used by politicians and policy makers to highlight issues to the attention of the general public, either through or directly to the media. 
Malaysians are living in a rapidly changing media environment. More people are having access to media forms that are totally different from the media of decades ago. The general population as the key voters, have used the mass media to obtain information on issues raised by candidates or their respective political parties when making their decisions during elections. The contributions made by the mass media are varied, depending on the constraints and inhibitions imposed upon the media, but a more free society will allow the press to raise issues less controlled by the political masters. The media are also seen as an open arena for public and rational deliberation in liberal democratic polities, through which the society and the government can maintain constant communication and through which the former exercises also an informal control over the latter (Guerrero and Nesbitt-Larking, 2010).

A less free environment will mean a more subdued press that has a tendency to restrict the issues that could be raised by the press. This study attempts to explain the role of the press during the 2008 General Elections through the perspective of agenda setting. Generally scholars have acknowledged the contribution of the mass media in affecting the outcome of elections by their ability to raise issues during election campaigns. Various approaches have been used in studying the role of the mass media in politics or during campaigns and elections, such as studying the relationship between the mass media institution, on one hand, and the political institution on the other hand. Scholars in political communication have also been studying symbols contained in the media institution itself.

The field of political communication as defined by Graber and Smith (2005), encompasses the construction, sending, receiving, and processing of messages that potentially has a significant direct or indirect impact on politics. In the former, an approach used has been on the agenda setting role of the mass media (McCombs and Shaw, 1972) or the effects media have on public opinion through the concept of the spiral of silence approach (Noelle-Neuman, 1979; Taylor, 1982). The two approaches have studied the extent to which issues raised by the media have been accepted by the public. This study will use the agenda setting approach indicating the relationship between the issues raised by the media and the issues held to be important by the public.

The methodology used is content analysis, a method that has been described as analyzing the manifest content of the media (Berelson, 1952; Neuendorf, 2002). This is a study on what selected Malaysian newspapers reported during the campaigns of the 2008 elections. It focused on the news items related to the elections. An analysis of media contents enables a study on what are reported by the media during the elections. Content analysis allows scholars to understand the role played by the mass media in selecting and reporting events considered as important for public consumption. Opinions, however, differ on what is to be considered as important between the media and the public. A content analysis provides the issues and the direction of the issues raised by the media. Although content analysis measures the manifest content of media, yet it does not preclude scholars from making inferences thus providing more depth in studying a specific issues.

A survey was conducted among 1,454 Malaysian respondents nation-wide to find out what issues were important to them. Respondents were asked an open-ended question on what they think were problems faced by the country that were of concern to them. The answers given were recorded and were then coded.

\section{Studying Elections}

Fundamentally, elections are important for the formation of a democratic government. Elections serve not only to select leaders acceptable to voters, but also make the leaders accountable for their performance during their tenure in office. The possibility of controlling leaders by requiring them to submit to regular and periodic elections help contribute to solving the problem of succession in leadership and thereby assist in the continuation of democracy. It could be argued that at the core of a democratic society is the presence of a public debate about the distribution and execution of power. It is crucial for democratic arrangements that choices made by the power holders are publicly scrutinised and contested. In the public debate, the informational and cultural products play a significant role. If the interests of the information and culture producers and the powers that be intertwined, a society's capacity for democratic government is seriously undermined (Hamelink, 1994).

Studies on elections in Malaysia have used varying approaches; from descriptive, analytical to empirical, not to mention those speculative in nature. Malaysia is one of the few developing countries that hold elections periodically as stipulated by the Federal Constitution thus allowing scholars or writers over the years to accumulate materials on politics and elections in the country, irrespective of methodologies used. Studies on politics and elections in Malaysia have been made by political scientists, by sociologists, psychologists and also by communication scholars.

Methodologies used have been varied too; ranging from field observation, surveys, and content analysis. Content analysis of Malaysian newspapers was made by Parker (1983) on the 1974 General Elections. Parker developed 
on Budd's (1964) score-like scale to obtain the measurements on prominence that Malaysian newspapers reported on the election. Other works using content analysis were soon to be used in later studies on Malaysian elections such as by Idid $(1994,2011)$.

The measurement used in content analysis was used to homogenize the differences in size and language among the English-, Chinese- and Malay-language newspapers. The varied approaches and methodologies used in studying politics and elections in Malaysia reflect varying interests on the subject. This study uses content analysis as its methodology on analyzing media contents and uses survey method to obtain opinion from the voters.

\section{Agenda Setting}

The perspective in this study lead to the rise of the agenda-setting function of the mass media based on the premise as summarized by Cohen (1963) that the media are not successful in telling the audience what to think, but it is stunningly successful in telling the audience what to think about. Under this theory or approach, the audience would decide for themselves what information they consider as important to them. The media are said to provide the information and the audience would select the information and would discuss among themselves about the information. Littlejohn (2002) sees this theory in a simple three-part linear process involving media agenda, public agenda, and policy agenda.

At this beginning stage of building media agenda setting, it falls under the first research tradition as to what has been advocated by Dearing and Rogers (1996) in the three research traditions of agenda setting. Before coming to the second research tradition or public agenda setting, the news salience from the media is sought by the public as something to think about. This is the stage where public opinion is shaped from media agenda. At the final stage, the policy actions in response to the public agenda and media agenda are the concern of the policy agenda setting. This third research tradition is most attracted to the political scientists.

As it is most frequently employed, the agenda-setting model predicts that the more an issue is covered by the media, the more the public will find the issue to be important. For example, Cook et al. (1983) demonstrate how the issue of fraud and abuse in home health care became a public issue due to media coverage by assessing public perceptions prior to and after the airing of an investigative report on the topic. In accordance with the agenda-setting model, they found that the public perceived the issue to be more important following vthe news report.

Electoral process and media coverage complement each other. Political parties and candidates require the attention of both the electronic and print media to portray their image and promote policy proposals for the attention and consideration of voters. Media access is important for political parties and candidates to reach out to the voters. On the other hand, the media also need the cooperation of political parties and candidates to use them as news for the interest of voters. The voters who are also the media audience, need to know more about these issues to enable them to decide whom they should vote for when they cast their votes. The issues raised during elections by political parties and the personalities involved are important ingredients for media coverage. As such, during election campaigns, the press are active in providing coverage of parties and personalities. In providing such coverage, they help in the electoral process of the country. Rogers et al. (1993) who used the term media agenda-setting instead of agenda-building noted that agenda-setting research has widely accepted the media agenda as a given and only a few studies have considered the process by which it is constructed. Hence, political issues that are most salient or accessible in a person's memory will most strongly influence perceptions of political actors and figures (Scheufele, 2000).

\section{The Media Scene}

Malaysia is well endowed with a good press system. The importance of media in the Malaysian society should not be over stressed. Given the present economic level and the level of literacy, there is a great demand for information from the media. Adult literacy has been $86 \%$ in 1987 , and has been increasing steadily to $92 \%$ in 2008. The expansion of schools in both the rural and urban areas over the past decades has paved the way for this improvement. Primary education is free while education at the university level is highly subsidized by the government. The literacy level has allowed for greater media use, especially the use of the print media. Greater literacy allows greater participation of citizens in the electoral process.

Media use in Malaysia can be considered as pervasive with more than $94 \%$ of the adults are reached by TV, compared to $83 \%$ reached by radio, and $73 \%$ by newspapers in 2008 . The government television channels and the private owned TV station, TV3 and radio programmes are available throughout the country. There are many characteristics of the print media that are evident in the country. While the electronic media has been mainly 
under government control since independence (and even before that), the print media has always been in private hands. Till the present time, Radio Malaysia and TV1 and TV2 are under the direction of the Ministry of Information, Communication and the Arts. It was until 1980's that the government allowed private organizations to run the TV stations.

Malaysia's print media industry is vigorous and is fast expanding in recent years, the print media has become highly profitable due to the advertisements collected during the past few years, and for some newspapers, there has been an increase in their circulations. Both the management of the print and electronic media has become innovative and is tapping the lucrative business of entertainment and information. The print media are available in various languages, namely in Malay, Chinese, Indian, and English. While the audience for the newspapers are general, the weeklies and the monthlies and magazines are more focused, either in terms of age groups, the gender, or the interests of the audience. The dailies in Sabah and Sarawak are smaller in circulation than those printed in Peninsular Malaysia because of the smaller market there. Peninsular-printed dailies have been penetrating the Sabah and Sarawak market because of the good printing system. The Peninsular-based dailies such as the New Straits Times, The Star, Berita Harian, and Sin Chew Daily are printed and have found their market in Sabah and Sarawak.

The mainstream press in Malaysia can be characterized as having gone through a major period of change, beginning in the early 1980s, coinciding with the period in which Mahathir Mohamad became prime minister. And this is apparently a trend that has extended into the 1990s. The early 1980s saw the emergence of new titles, signifying to many a liberalization of media policies, a relaxation of control (Zaharom Nain, 2002).

Mass media play a key role in informing the citizens about issues. This informational function is important in a number of respects, most importantly the strong link between levels of current-events knowledge and participation in various political activities (Kim et al., 2002). Coverage of election issues and on matters connected with the candidates and parties allow discussion among the voters. This would kindle interest in the electoral process as citizens feel and become involved. Voters would then attend ceramahs (small rallies) or gather more information about their candidates and parties before making the final decision. How does the press obtain the news to be placed in their pages or space? Some reporters would interview the candidates or leaders of the political parties and seek their opinion or comments on controversial matters. This is problematic at times because of the pressures of election campaigns. Leaders have to meet with the voters. This meeting usually begin from the early hours of the morning to the late hours of the night. But leaders realize the importance of access to the media and would provide time for an interview with reporters.

The second way is for reporters to listen to the ceramahs and to report what they consider as newsworthy statements. In such ceramahs, political leaders would comment on the issues of the day and this would provide the reporters with the materials to write their news. The disadvantage of following ceramahs is because of the lateness of the hour. In many cases, ceramahs are held at night, often than not beginning from $8.00 \mathrm{pm}$. The main speaker would be speaking later. To reporters, the deadline for sending the news would be too late. The alternative is for the news to appear the very next day.

\section{The Present Study}

In agenda-setting studies, two methods of research are normally used, namely content analysis and survey research. This is understandable as two different types of population are being studied and the findings on the two of the population are then used in a correlational manner to find their items of concern. Content analysis is a method used to uncover the news items by the media in the 2008 General Elections. Content analysis is widely used in every election study by Idid $(1994,2011)$ to understand the sources, the types of news, the direction and the prominence given to them.

The second method is a survey to find out the opinion of voters on topics that are relevant to the election. In this study, a survey was conducted on the voters to know their areas of concern. Respondents were asked on their perception of the well being of the country, their use of the media, their assessment on the credibility of the media, and the problems that the country were facing. For this report, the study would only use the what the respondents felt were problems faced by the country.

The public opinion study was conducted in March 2008. A total of 1,454 respondents were chosen nation wide by quota sampling. Respondents were asked through an open-ended question what they perceived to be the problems faced by the country. For the purpose of this study all the answers given by the respondents were then recorded and were later slotted into 12 categories. 
This study focuses on the news items related to the elections in selected Malaysian newspapers. Attempts have been made in this paper to compare the issues, as well as the sources and directions of news that were raised by the press during the campaign period of 2008 General Elections. Content analysis was used as a means to collect data. Content analysis as a form of methodology has its advantages but there are also disadvantages in using it (Weber, 1990). For an analysis of newspaper contents during elections, the content analysis is considered most appropriate despite some inherent disadvantages. In this study, six newspapers were examined, namely Utusan Malaysia, Berita Harian, Sin Chew Daily, Nanyang Siang Pau, The Star, and New Straits Times. The study was from 24 February to 8 March, 2008.

The six newspapers in the three different languages reflect the two major ethnic characteristics, i.e., the Malay and Chinese, of the plural Malaysian society. The six dailies were major newspapers in their respective languages. In 2008, they had a combined circulation of almost 2.5 million, with an estimated readership of close to five million or more than $50 \%$ of the adult populations in Peninsular Malaysia. Table 1 depicts the circulation, readership and penetration rate of the respective newspapers.

$<$ Insert Table 1 Here $>$

\section{Research Findings}

A total of 9,135 news items were collected relevant to the present study. The majority of the news items came from the Chinese newspapers (48\%), followed by Malay language newspapers (28\%) and the English diailies (24\%). As an individual newspaper, Sin Chew Daily gave 28\% coverage on the elections, Nanyang Siang Pau (20.3\%), Berita Harian (14.4\%), Utusan Malaysia (14.0\%), New Straits Times (12.0\%), and The Star (11.6\%) (see Table 2).

\section{$<$ Insert Table 2 Here $>$}

The study took the 9,135 news items and ranked them into 12 categories. There were 25 units of analysis from the Chinese newspapers that did not match any of the pre-determined categories. Overall, most of the news items were devoted on the candidates contesting the elections, followed by news reports on campaigns, then on the strengths and weaknesses of the opposition parties, followed by other categories that are seen in Table 3 . The religious issues and government administration were the two least prominent in the list. There were slight variations among the newspapers of three language newspapers. The top two prominent issues in sequence for Chinese and English newspapers were the candidates contesting and campaigns. It was different for the Malay dailies. The different language newspapers varied in their coverage for the third important issue. Coverage on the strengths and weakneses of the opposition parties was placed third by the English dailies but the Malay newspapers chose policy on development and unity while reporting on leadership was the third choice ranked by the Chinese newspapers.

$<$ Insert Table 3 Here $>$

A survey was conducted after the elections to find the issues that were considered as important to the respondents. In the survey, respondents were asked an open-ended question requiring them to provide a single issue that they felt affected the nation the most. Out of the total answers, the authors grouped the issues into 12 categories as what was done similarly in the content analysis grouping. In terms of frequencies mentioned, economic issue was felt the most by respondents, followed by the policy on development and unity, and then on the leadership qualities (see Table 4). The top two issues, on the economy and the policy on development and unity, were also most frequently mentioned among the Malay and Chinese communities.

\section{$<$ Insert Table 4 Here $>$}

The authors then arranged the two findings from the content analysis and from the public opinion survey so as to make comparisons between the media coverage and the public issues (see Table 5). The findings are to ascertain the rank-order correlation between the media agenda and public agenda. The study found that there was a difference in what the media placed in terms of importance and what the public thought were important to them. To the general public, the voters, the issue that they felt affected the nation the most was the economic issue but the economic issue was given ninth placing by the media. The public felt that the policy on unity and development was the second most important issue, followed third by the issue on leadership, but the press ranked them as number five and number eight. The public and the press were agreed that the issue on religion was the least important among the 12 issues categorized.

$<$ Insert Table 5 Here $>$ 
In running the non-parametric testing for the relationship between the two agenda, the results showed that Spearman's rho, $r(10)=.371$ with $p=.118$; meaning that there was no significant rank-order correlation between the overall media agenda $(\mathrm{N}=9,110)$ with the overall public agenda $(\mathrm{N}=1,454)$. This implies that in the perspective of agenda setting, whether media were capable to set the agenda in a multiethnic society like Malaysia.

The study then compared the Malay language and Chinese language media agenda with the Malay and Chinese respondents to understand the importance that the respective newspapers and the respondents ranked on issues. It was found that the Malay and the Chinese respondents ranked economy as the number one issue facing the country, followed by the policy on development and unity as number two. However, both Malay and Chinese newspapers ranked economy as number nine; with the Malay newspapers ranked policy on development and unity as number three but the Chinese newspapers ranked it lower as number five. Media in both languages ranked reports on candidates contesting and campaigns as the two most prominent issues but the Malays and Chinese readers ranked them as fourth and sixth most important. Malay newspapers ranked policy on development and unity as third most prominent issue but Malay readers ranked it higher as the second most important. Coincidentally, both Chinese newspapers and their readers placed leadership quality as the third most important in terms of ranking. The ranking of the other issues by ethnic are in Table 6 .

$<$ Insert Table 6 Here $>$

In terms of the agenda-setting function of media, the Malay newspapers did not appear to set the public agenda for its readers. The test statistics $(r(10)=.441$ with $p=.075)$ suggested a no significant rank-order correlation between the Malay media agenda $(\mathrm{n}=2,587)$ and the Malay public agenda $(\mathrm{n}=889)$ at $95 \%$ confidence level. The test results $(r(10)=.559$ with $p=.029)$ for the Chinese indicated a significant rank-order correlation between the Chinese media agenda $(n=4,368)$ and Chinese public agenda $(n=426)$. There is therfore a differential scenario where the agenda-setting function of media only occurred within the Chinese community.

\section{Conclusion}

This study was carried out to understand the nature of media converage and the issues deemed as important by the general public by using the perspective of agenda setting. The setting during the 12th Malaysian General Election took place in March 2008. A content analysis was made on six newspapaers during the campaign week from 24 February to 8 March, 2008 to collect the issues that were frequently reported by the press. The issues were grouped into 12 categories.

A study was made on the voters on the issues that they felt affected the nation the most. Again the issues were grouped into 12 categories and ranked in terms of the frequency of mention. The two sets of issues, ranked between the media and the public agenda, did not correlate with one another, suggesting that the public did not perceive the importance of issues as equally important as that ranked by the media.

When comparison was made with the issues ranked by the Malay and Chinese respondents, the results showed that there were some differences between the respective media and the readers of these two ethnic groups. The Malays and the Chinese ranked economic problems and the policy on development and unity as the two most important issues affecting the nation which varied accordingly with the ranking of the press. In terms of agenda setting, there was no significant correlation between the media agenda and the public agenda and also between the Malay and the Malay media agenda.

The findings showed a different case for the Chinese community as the Chinese media agenda was significantly correlated with the Chinese public agenda. This indicates that the Chinese newspapers played its role during the general elections by influencing the Chinese community on what to think about. In other words, this ethnic community took the newspapers as a key channel for political communication during election time and likewise the Chinese newspapers were able to understand the important issues that were felt by their readers.

Generally, the study found that the mass media did not highlight issues that were considered as important by the readers in Malaysia during election time. To the party strategists, ground was lost when the voters were not highlighted on the issues that were important to them. The findings suggest that if issues were regarded as significant in affecting the votes, then these issues ought to be highlighted. Politicians need to understand better that what were covered by the media did not necessarily correspond with the issues considered as significant by the voters.

\section{References}

Berelson, B. (1952). Content analysis in communication research. New York: Free Press. 
Budd, R. (1964). Attention score: A Device for measuring news play. Journalism Quarterly, 41, $259-262$. http://dx.doi.org/10.1177/107769906404100215

Cohen, B. B. (1963). The press, the public and foreign policy. Princeton: Princeton University Press.

Cook, F. L., Tom, R.T., Edward, G. G., Margaret, T. G., David, P., Donna, R. L. \& Harvey, L. M. (1983). Media and agenda setting: Effects on the public, interest group, leaders, policy makers, and policy. Public Opinion Quarterly, 47, 16-35. http://dx.doi.org/10.1086/268764

Dearing, J. W. \& Rogers, E. M. (1996). Agenda-setting. California: Sage.

Graber, D. A. \& Smith, J. M. (2005). Political communication faces the 21st century. Journal of communication, 55(3), 479-507. http://dx.doi.org/10.1111/j.1460-2466.2005.tb02682.x

Guerrero, M. A. \& Nesbitt-Larking, P. (2010). Media and democracy: Recent experiences from Canada and Mexico - An introduction. Journal of Policy and Society, 29, 1-11. http://dx.doi.org/10.1016/j.polsoc.2009.11.001

Hamelink, C. J. (1994). Trends in world communication: On disempowerment and self-empowerment. Penang: Southbound.

Idid, Syed Arabi. (1994). Penentuan agenda: Peranan media massa dalam pilihanraya umum. Kuala Lumpur: Dewan Bahasa dan Pustaka.

Idid, Syed Arabi. (2011). Peranan media massa dalam pilihan raya umum. Gombak: International Islamic University Malaysia Press.

Kim, S. H., Scheufele, D. A. \& Shanahan, J. (2002). Think about it this way: Attribute agenda setting function of the press and the public's evaluation of local issue. Journal of Media and Communication Quarterly, 79(1), 7-25. Littlejohn, S. W. (2002). Theories of human communication (7th ed). Belmont: Wadsworth.

McCombs, M. E. \& Shaw, D. (1972). The agenda-setting function of mass media. Public Opinion Quarterly, 36, 176-187. http://dx.doi.org/10.1086/267990

Neuendorf, K. A. (2002). The content analysis guidebook. Thousand Oaks, CA: Sage Publications.

Noelle-Neumann, E. (1979). Public opinion and the classical tradition: A re-evaluation. Public Opinion Quarterly, 43(2), 143-156. http://dx.doi.org/10.1086/268507

Parker, E. S. (1983). Correlation between items and space across languages. Journalism Quarterly, 66(1), 144-146. http://dx.doi.org/10.1177/107769908306000126

Rogers, E. M., Dearing, J. W. \& Bregman, D. (1993). The anatomy of agenda-setting research. Journal of Communication, 43, 68-84. http://dx.doi.org/10.1111/j.1460-2466.1993.tb01263.x

Scheufele, D. A. (2000). Agenda-setting, priming, and framing revisited: Another look at cognitive effects of political communication. Journal of mass communication and society, 3(2-3), 297-316.

Taylor, D. G. (1982). Pluralistic ignorance and the spiral of silence: A formal analysis. Public Opinion Quarterly, 46(3), 331-335. http://dx.doi.org/10.1086/268729

Weber, R. P. (1990). Basic content analysis (2nd ed). CA: Newbury Park.

Zaharom Nain. (2002). The structure of the media industry, implications for democracy. In Loh, K. W. \& Khoo, B.

T. (Eds). Democracy in Malaysia: Discourses and practices (pp. 111-137). Curzon: Nordic Institute of Asian Studies.

Table 1. Circulation and readership by newspapers in 2008

\begin{tabular}{llcl}
\hline Medium & Daily & Circulation & Readership \\
\hline Malay & Utusan Malaysia & 656,248 & $1,000,230$ \\
& Berita Harian & 516,253 & $1,143,120$ \\
Chinese & Sin Chew Daily & 383,775 & $1,139,000$ \\
& Nanyang Siang Pau & $\mathrm{N} / \mathrm{A}$ & 174,000 \\
English & The Star & 618,513 & $1,143,120$ \\
& New Straits Times & 293,440 & 285,780 \\
\hline Overall & & $2,468,229$ & $4,885,250$ \\
\hline
\end{tabular}

Source: Adapted from Nielsen Media Index, 2008; Audit Bureau of Circulations, 2010 
Table 2. News items analysed

\begin{tabular}{llll}
\hline Medium & Daily & Frequecy (Percent) & Frequency (Percent) \\
\hline Malay & Utusan Malaysia & $1,276(14.0)$ & \\
& Berita Harian & $1,311(14.4)$ & $2,587(28.4)$ \\
Chinese & Sin Chew Daily & $2,538(27.8)$ & \\
& Nanyang Siang Pau & $1,855(20.3)$ & $4,393(48.1)$ \\
English & The Star & $1,063(11.6)$ & $2,155(23.6)$ \\
& New Straits Times & $1,092(12.0)$ & $9,135(100)$ \\
\hline Overall & & & \\
\hline
\end{tabular}

Table 3. Ranking of coverage by newspaper

\begin{tabular}{lllll}
\hline Category & \multicolumn{4}{l}{ Media Agenda } \\
\cline { 2 - 3 } & $\begin{array}{l}\text { Overall } \\
(\mathrm{N}=9,110)\end{array}$ & $\begin{array}{l}\text { Malay } \\
(\mathrm{n}=2,587)\end{array}$ & $\begin{array}{l}\text { Chinese } \\
(\mathrm{n}=4,368)\end{array}$ & $\begin{array}{l}\text { English } \\
(\mathrm{n}=2,155)\end{array}$ \\
\hline Candidate contesting & 1 & 2 & 1 & 1 \\
Campaigns & 2 & 1 & 2 & 2 \\
Strengths/weaknesses of opposition & 3 & 4 & 7 & 3 \\
Strengths/weaknesses of BN & 4 & 5 & 4 & 4 \\
Policy on development and unity & 5 & 3 & 5 & 8 \\
Attitudes of voters & 6 & 8 & 6 & 5 \\
Election Commission & 7 & 6 & 8 & 7 \\
Leadership quality & 8 & 7 & 3 & 6 \\
Economy & 9 & 9 & 9 & 9 \\
National security & 10 & 11 & 10 & 11 \\
Government administration & 11 & 12 & 11 & 12 \\
Religious issues & 12 & 10 & 12 & \\
& & & & \\
\hline
\end{tabular}

Table 4. Ranking of important issues by ethnicity

\begin{tabular}{lcccc}
\hline Category & \multicolumn{3}{c}{ Public Agenda } & \\
\cline { 2 - 4 } & $\begin{array}{l}\text { Overall } \\
(\mathrm{N}=1,454)\end{array}$ & $\begin{array}{l}\text { Malay } \\
(\mathrm{n}=889)\end{array}$ & $\begin{array}{l}\text { Chinese } \\
(\mathrm{n}=426)\end{array}$ & $\begin{array}{l}\text { Indian } \\
(\mathrm{n}=139)\end{array}$ \\
\hline Economy & 1 & 1 & 1 & 1 \\
Policy on development and unity & 2 & 2 & 2 & 2 \\
Leadership quality & 3 & 3 & 3 & 4 \\
Campaigns & 4 & 6 & 6 & 3 \\
Candidate contesting & 5 & 4 & 4 & 8 \\
Strengths/weaknesses of BN & 6 & 5 & 5 & 6.5 \\
Strengths/weaknesses of opposition & 7 & 7 & 7 & 5 \\
National security & 8 & 8 & 9 & 6.5 \\
Government administration & 9 & 9.5 & 10 & 10 \\
Election Commission & 10 & 9.5 & 11 & 9 \\
Attitudes of voters & 11 & 11 & 12 & 11 \\
Religious issues & 12 & 12 & & 12 \\
& & & & \\
\hline
\end{tabular}


Table 5. Correlating the overall media agenda and overall public agenda

\begin{tabular}{lll}
\hline Category & $\begin{array}{l}\text { Overall Media Agenda } \\
(\mathrm{N}=9,110)\end{array}$ & Overall Public Agenda \\
& $(\mathrm{N}=1,454)$
\end{tabular}

\begin{tabular}{lcc}
\hline Candidate contesting & 1 & 5 \\
Campaigns & 2 & 4 \\
Strengths/weaknesses of opposition & 3 & 7 \\
Strengths/weaknesses of BN & 4 & 6 \\
Policy on development and unity & 5 & 2 \\
Attitudes of voters & 6 & 11 \\
Election Commission & 7 & 10 \\
Leadership quality & 8 & 3 \\
Economy & 9 & 1 \\
National security & 10 & 8 \\
Government administration & 11 & 9 \\
Religious issues & 12 & 12 \\
\end{tabular}

Table 6. Correlating the media agenda and public agenda by ethnic

\begin{tabular}{|c|c|c|c|c|}
\hline \multirow[t]{2}{*}{ Category } & \multicolumn{2}{|c|}{ Media Agenda } & \multicolumn{2}{|c|}{ Public Agenda } \\
\hline & $\begin{array}{l}\text { Malay } \\
(\mathrm{n}=2,587)\end{array}$ & $\begin{array}{l}\text { Chinese } \\
(n=4,368)\end{array}$ & $\begin{array}{l}\text { Malay } \\
(\mathrm{n}=889)\end{array}$ & $\begin{array}{l}\text { Chinese } \\
(\mathrm{n}=426)\end{array}$ \\
\hline Candidate contesting & 2 & 1 & 4 & 4 \\
\hline Campaigns & 1 & 2 & 6 & 6 \\
\hline Strengths/weaknesses of opposition & 4 & 7 & 7 & 7 \\
\hline Strengths/weaknesses of BN & 5 & 4 & 5 & 5 \\
\hline Policy on development and unity & 3 & 5 & 2 & 2 \\
\hline Attitudes of voters & 8 & 6 & 11 & 11 \\
\hline Election Commission & 6 & 8 & 9.5 & 8 \\
\hline Leadership quality & 7 & 3 & 3 & 3 \\
\hline Economy & 9 & 9 & 1 & 1 \\
\hline National security & 11 & 10 & 8 & 9 \\
\hline Government administration & 12 & 11 & 9.5 & 10 \\
\hline Religious issues & 10 & 12 & 12 & 12 \\
\hline
\end{tabular}

